\title{
Studies on the Interspecific Hybrids between Mungbean and Urdbean
}

\author{
Satish Kumar Singh*, M. N. Singh, V. K. Choudhary, M. K. Singh and Aman Tigga \\ Department of Plant Breeding and Genetics, Dr. Rajendra Prasad Central Agricultural \\ University, Pusa, Samastipur, India \\ *Corresponding author
}

\begin{abstract}
A B S T R A C T
Thirty interspecific crosses (including reciprocals) involving three genotypes/varieties of greengram (Vigna radiate $(L)$ Wilczek) cv. HUM 1 HUM $2 \&$ HUM 8 and five genotypes/varieties of blackgram (Vigna mungo (L.) Hepper) cv. T 9, Pant U 19, PDU 1, BHUU 1 \& BHUU 91-346-1 were attempted. Nine out of 30 crosses were successful only when greengram was used as seed parents. The crossability ranged from 0.0 to 61.0 per cent. Germination, survival and pod bearing habit of the $\mathrm{F}_{1} \mathrm{~s}$ hybrids were much better in Kharif season as compared to spring/summer season. The $\mathrm{F}_{1}$ hybrids were intermediate for leaf shape, pod and stem hairiness and pod arrangement while they resembled the maternal parents for cotyledon colour. Purple colour of the stem appeared to be dominant over green colour. The $\mathrm{F}_{1} \mathrm{~s}$ showed positive heterosis for days to flowering and maturity, plant height, number of primary branches, pods per plant and cluster per plant while for pod length, number of seeds per pod, seed yield per plant and 100-seed weight, it exhibited negative heterosis. The mean of the pollen fertility was 15.0 per cent in $\mathrm{F}_{1} \mathrm{~s}$ and 32.5 per cent in $\mathrm{F}_{2} \mathrm{~S}$ indicating the improvement in fertility level when generation advanced. In $\mathrm{F}_{2}$ generation, the hybrids segregated both for greengram and blackgram types. Further, the desirable transgressive segregants were observed in $\mathrm{F}_{2}$ generation for most of the traits indicated that an elite population may be obtained through interspecific hybridization involving greengram and blackgram
\end{abstract}

\section{Keywords}

genotypes/varieties of blackgram and stem hairiness pod arrangement

Article Info

Accepted: 05 April 2020 Available Online: 10 May 2020

\section{Introduction}

Among the several pulses grown, greengram [Vigna radiata (L.) Wilczek] and blackgram [Vigna mungo (L.) Hepper] are the important grain legumes cultivated through the world. In India, greengram and blackgram are usually grown in Kharif as well as Spring/Summer season. Due to their short duration, they can be well fitted in multiple cropping systems ultimately adding to the total production.
Grain legumes are a good source of nonvegetarian protein, especially for the poor men who often cannot afford animal protein.

It also contains high amounts of macro and micronutrients, vitamins, fibre and carbohydrate for balanced nutrition (Gill et al., 2014; Kumar et al., 2016 and 2017). It also improves the soil health by fixing the atmospheric nitrogen in to the soil and enhances the yield of subsequent crop (Jat et 
al., 2012). The average yield of pulses in general and greengram in particular is very low as compared to that of cereals because of the lack of suitable high yielding varieties, non-synchronous maturity, instability under varying environmental conditions and susceptibility to different diseases and pests. Thus there is an open challenge on the part of the plant breeder to develop such as a breeding programmes in greengram which can bring a revolutionary genetic improvement for high yield potential, resistant to diseases and pests and wider adaptability, especially of short duration (below 60 days), which may be well fitted in wheat/rice cropping system which occupy a major irrigated area of the country. Genetic variability is the backbone of any crop improvement programme.

The significance and importance of interspecific hybridization in crop improvement through widening the genetic variability have been recognized in several crops. A successful interspecific hybridization programme is an important means of introgression of desirable genes of one species to the other species. Greengram is an important pulse crop and cultivated in all cropping seasons in India. Due to short duration nature, it is well fitted in wheat-rice cropping system, which is prevalent in northern plain.

Hence, it contributes to increase the income of the farmers. Greengram has many desirable traits such as erect growth habit, large number of seeds per pod and easily digestible protein, whereas blackgram possesses non-shattering pods and were usually resistant to Cercospora Leaf Spot (CLS). The desirable traits can be transferred from one species to another by interspecific hybridization. Varying degrees of success in interspecific hybridization involving greengram and blackgram have been reported in the literature. However, interspecific hybrids obtained were often completely sterile (Chowdhary et. al., 1977) or partially fertile (Gosal \& Bajaj 1983; Singh \& Singh, 1991; Singh et. al. 1996 \& 1997) and usually produced parental types in segregating generation (Smart, 1970). However, these results were mostly based on one or few hybrids and lesser number of $\mathrm{F}_{2}$ progenies.

Studies based on larger number of crosses involving diverse genotypes could provide a better understanding of various aspects related with crossability, extent of variability and segregation pattern for different qualitative and quantitative traits in the derivative of interspecific hybrids involving greengram and blackgram. In view of the above facts, the present investigation was carried out to assess the interspecific hybridization as a method of improving these crops

\section{Materials and Methods}

Three cultivars/genotypes of green gram (HUM 1, HUM 2 \& HUM 8) and five cultivars/ genotypes of blackgram ( $\mathrm{T}$ 9, Pant U19, PDU 1, BHUU 1 and BHUU 91-346-1) were raised in crossing block. Crosses were made in line $\mathrm{x}$ tester fashion to obtain 30 (including reciprocals) interspecific hybrids. Nine $\mathrm{F}_{1} \mathrm{~s}$ along with their parents were sown in cemented pots during Kharif and data were recorded for eleven characters of all the plants of $F_{1} s$ and 10 randomly selected plants of the parents (Table 1). Fresh $\mathrm{F}_{1}$ 's were also procured. The final experiment comprising of nine each of $F_{1} s$ and $F_{2} s$ along with their parents were grown in randomized block design with two replications at Agricultural Research Farm, Institute of Agricultural Sciences, BHU, during, Spring/Summer. Each plot was consisted of single row of $2 \mathrm{~m}$ length with spacing of 30 and $10 \mathrm{~cm}$ between and within rows respectively. 
Parents and $F_{1}$ 's had single row each while each $\mathrm{F}_{2} \mathrm{~s}$ had 3-5 rows. Data were recorded from 10 randomly selected plants from each row for eleven quantitative traits (Table-1) as well as twelve morphological traits (Table-2).

\section{Results and Discussion}

Thirty crosses were attempted in line $\mathrm{x}$ tester fashion involving three greengram and five blackgram genotypes. Nine out of thirty crosses were successful only when the greengram was used as seed parent. The crossability ranged from 0.0 to 61.6 per cent (HUM 1 X BHUU1) and thus showed wide variation from one cross to another which was in conformity with earlier report of Singh et. al. (1996) and Subramanian and Muthiah (2001B). The poor crossability may be due to injury during crossing and some physiological mechanism like formation of abscission layer (Subramanian and Muthiah, 2001 B). Another possible factors affecting crossability ought to be the genotypic differences and ecological variation of the genotypes used in the present investigation. In reciprocal crosses, either there was no pod setting at all or the pods abscissed in early stage and if pod developed, contained enviable seeds. Failure of the reciprocal crosses could be attributed due to pre-and post-fertilization barriers.

Subramanian and Muthiah, (2001A) reported that there was disintegration of pollen tube throughout the stylar region and if some of the pollen tubes gained entry into the micropylar end, they were subsequently obstructed at the point of their entry and hence fertilization could not be effected. In post fertilization, there was early abscission of the pod and embryo abortion (Gossal and Bajaj, 1983). The parental seeds were fully developed and smooth whereas, the crossed seeds were shrivelled due to poorly developed endosperm. Germination of the $\mathrm{F}_{1} \mathrm{~s}$ hybrids during, Kharif, varied from 0.0 (HUM 8 X
Pant U 19 and HUM 8 X BHUU 91-346-1) to 60 per cent (HUM 2 X BHUU 91-346-1), average 24.0 per cent as compared to 96.6 per cent in the parental lines. However, the germination of the $F_{1}$ progenies sown in the field during, Spring, ranged from 0.0 to 26.6 per cent (HUM 1 X BHUU 1) with a mean of 7.9 per cent as compared to 95 per cent in the parental line (Table-3). Similarly the survival of the $\mathrm{F}_{1}$ progenies sown during, Kharif, ranged from 33.3 (HUM 2 X T 9) to 100 per cent (HUM 1X BHUU 1, HUM 1 X T 9, HUM 8 X T 9 and HUM 1 X PDU 1) average 77 per cent as compared to 100 per cent in the parental lines. In contrast, the survival of the $\mathrm{F}_{1} \mathrm{~s}$ hybrids, ranged from 0.0-75 per cent (HUM 1 X BHUU1) average only 30.8 per cent during, Spring (Table 3).

The differences in the germination and survival of the $F_{1} s$ hybrids depend upon the genotypic differences of the parental lines involved in the crosses as well as the environmental conditions, for example, during, Spring, the seedlings of the crosses, HUM 2 X T 9 and HUM 2 X BHU 91-346-1, grew slowly and died in early stages (before 30 days) whereas, the seedlings of the cross, HUM 2 X BHUU 1, grew normally at early stages but due to bud necrosis and leaf crinckling, eventually died after 80-100 days. However, the same cross i.e. HUM $2 \mathrm{X}$ BHU 1 grew normally and at least 50 per cent of the plants attained pod maturity during, Kharif season. Similarly, in cross, HUM 2 X PDU1, though 75 per cent of the seedling bore mature pod during Kharif season none of the plant even came into flowering during Spring season.

The better germination, survival and pod bearing habit of the $\mathrm{F}_{1} \mathrm{~s}$ in Kharif season as compared to Summer season could be due to favourable environmental conditions. It is, therefore, suggested that for better germination, survival and pod bearing habit of 
the inter- specific $\mathrm{F}_{1}$ hybrids, Kharif season seemed to the best as compared to Spring season. Of the twelve morphological traits, the $F_{1}$, hybrids resembled the paternal parents for as many as five traits such as stem colour, leaf colour, calyx colour, standard petal colour and mature pod colour (Table 2) and were intermediate for pod and stem hairiness and pod arrangement. However, the $\mathrm{F}_{1} \mathrm{~s}$ resembled the maternal parent for cotyledon colour (Singh and Singh, 2006). These clearcut morphological differences could be the most useful criteria for the identification of the true hybrids. In $\mathrm{F}_{2}$ generation, the stem colour varied from green to deep purple and seed colour varied from green to mosaic green and greenish black to brownish black. For plant habit, $F_{2}$ segregants showed a wide variations viz, erect, bushy and intermediate type. The $\mathrm{F}_{1}$ hybrids flowered profusely, but pod setting was very low. This was due to low pollen fertility, which ranged from 5.3 to 23.0 per cent. Low pollen fertility in such hybrids has been reported earlier (Subramanian, 1980, Singh et. al. 1997 and Subramanian and Muthiah, 2001 B).

Table.1 Mean, Range \& Coefficient of Variation (CV\%) of parents, $\mathrm{F}_{1}$ and $\mathrm{F}_{2}$ progenies of interspecific crosses involving greengram and blackgram during Spring

\begin{tabular}{|c|c|c|c|c|c|c|c|}
\hline \multirow[t]{2}{*}{ Character } & \multicolumn{2}{|c|}{ Greengram } & \multicolumn{2}{|c|}{ Blackgram } & \multicolumn{2}{|c|}{ F1/F2 progenies } & \multirow[t]{2}{*}{ CV\% } \\
\hline & Range & Mean & Range & Mean & Range & Mean & \\
\hline $\begin{array}{c}\text { Days to } \\
\text { Flowering }\end{array}$ & $36-42$ & 39.2 & $38.0-45.0$ & 41.5 & $\begin{array}{l}F_{1} 41.0-49.0 \\
F_{2} 34.0-80.0\end{array}$ & $\begin{array}{l}47.0 \\
44.0\end{array}$ & 22.4 \\
\hline $\begin{array}{c}\text { Days to } \\
\text { Maturity }\end{array}$ & $75.8-82.0$ & 79.5 & $81.0-85.0$ & 83.4 & $\begin{array}{c}F_{1} 104.0-115.0 \\
F_{2} 95.0-144.0\end{array}$ & $\begin{array}{l}107.0 \\
125.0\end{array}$ & $\begin{array}{c}- \\
15.3\end{array}$ \\
\hline $\begin{array}{c}\text { Plant Height } \\
\text { (cm) }\end{array}$ & $48.0-54.5$ & 51.5 & $39.0-42.4$ & 40.6 & $\begin{array}{l}F_{1} 28.5-114.0 \\
F_{2} 26.4-134.5\end{array}$ & $\begin{array}{l}93.6 \\
64.8\end{array}$ & 50.6 \\
\hline $\begin{array}{c}\text { No. of } \\
\text { Primary } \\
\text { Branches }\end{array}$ & $2.4-5.0$ & 3.4 & $2.2-4.2$ & 3.2 & $\begin{array}{l}F_{1} 4.0-6.8 \\
F_{2} 5.2-9.0\end{array}$ & $\begin{array}{l}5.2 \\
6.4\end{array}$ & $\begin{array}{c}- \\
17.2\end{array}$ \\
\hline $\begin{array}{c}\text { No. of } \\
\text { Secondary } \\
\text { Branches }\end{array}$ & $0.0-2.5$ & 2.1 & $0.0-4.8$ & 2.2 & $\begin{array}{l}F_{1} 0.0-6.0 \\
F_{2} 0.0-7.0\end{array}$ & $\begin{array}{l}3.8 \\
4.6\end{array}$ & 39.8 \\
\hline Clusters/Plant & $9.2-14.5$ & 13.4 & $14.6-16.8$ & 15.5 & $\begin{array}{l}F_{1} 7.7-52.5 \\
F_{2} 2.0-38.5\end{array}$ & $\begin{array}{l}38.6 \\
26.1\end{array}$ & $\begin{array}{c}- \\
50.1\end{array}$ \\
\hline Pods/Plant & $30.0-44.5$ & 34.2 & $25.0-33.0$ & 32.8 & $\begin{array}{l}F_{1} 18.0-96.8 \\
F_{2} 0.0-115.0\end{array}$ & $\begin{array}{l}52.3 \\
58.9\end{array}$ & $\begin{array}{c}- \\
74.7\end{array}$ \\
\hline $\begin{array}{l}\text { Pod length } \\
\quad(\mathrm{cm})\end{array}$ & $6.2-7.0$ & 6.4 & $3.4-4.8$ & 4.2 & $\begin{array}{l}F_{1} 1.5-2.2 \\
F_{2} 1.8-5.8\end{array}$ & $\begin{array}{l}1.7 \\
3.4\end{array}$ & $\begin{array}{c}- \\
40.4\end{array}$ \\
\hline Seeds/Pod & $8.0-12.0$ & 9.8 & $5.0-8.0$ & 3.4 & $\begin{array}{l}F_{1} 1.0-3.0 \\
F_{2} 1.0-6.0\end{array}$ & $\begin{array}{l}1.3 \\
2.6\end{array}$ & $\begin{array}{l}- \\
43.8\end{array}$ \\
\hline $\begin{array}{c}\text { 100-Seed } \\
\text { Weight (g) }\end{array}$ & $3.7-4.4$ & 3.9 & $3.8-4.3$ & 4.2 & $\begin{array}{ll}F_{1} & 2.9-3.6 \\
F_{2} & 2.5-4.4\end{array}$ & $\begin{array}{l}3.2 \\
3.4\end{array}$ & 27.9 \\
\hline $\begin{array}{c}\text { Yield/Plant } \\
\text { (g) }\end{array}$ & $9.8-11.2$ & 10.8 & $4.7-7.3$ & 5.9 & $\begin{array}{c}F_{1} 0.8-2.6 \\
F_{2} 0.5-10.5\end{array}$ & $\begin{array}{l}1.8 \\
2.7\end{array}$ & $\begin{array}{c}- \\
85.5\end{array}$ \\
\hline
\end{tabular}


Table.2 Comparison of morphological characters of greengram, blackgram and their interspecific hybrids

\begin{tabular}{|l|c|c|c|}
\hline Character & Vigna radiate & V.radiata X V. mungo & V. mungo \\
\hline Cotyledon & Yellow & Yellow & White \\
\hline Stem colour & Green & Purple & Purple \\
\hline Stem hairiness & Sparsh to moderate & Moderate & Sparsh to profuse \\
\hline Leaf shape & Ovate & Intermediate & Lanceolate \\
\hline Leaf colour & Light green & Dark Green & Dark Green \\
\hline Calyx colour & Green with purple tinge & Green & Green \\
\hline Standard petal colour & Ashy Yellow & Dark Yellow & Dark Yellow \\
\hline Pod arrangement & Sparse & Moderate & Profuse \\
\hline Mature pod colour & Black & Blackish Brown & \begin{tabular}{c} 
Blackish Brown \\
\hline Pod hairiness
\end{tabular} \\
\hline Seed colour & Non-hairy & Slightly hairy & Densely hairy \\
\hline Plant habit & Green & Greenish black to brownish & Brownish black to \\
& black & greenish mosaic \\
\hline
\end{tabular}

Low pollen fertility may be due to meiotic abnormalities such as non-orientation of bivalents at metaphase and precocious disjunction, which indicate failure of genes controlling meiotic process. Dana (1967) and Ahandabaskarn and Rangasamy (1996) have also observed similar results in such crosses. However, the pollen fertility of the $F_{2}$ progenies ranged from 11.0 to 91.8 per cent with a mean of 32.5 per cent as compared to $\mathrm{F}_{1}, \mathrm{~s} \quad(15.0$ per cent) indicating the improvement in fertility when generation is advanced.

In $\mathrm{F}_{1}$ hybrids, the positive heterosis was recorded for days to flowering and maturity, plant height, number of primary and secondary branches, pods per plant and cluster per plant as was also observed by Shanmungam et. al. (1985), Subramanian and Muthiah (2001B) and Singh et al., (2009 \& 2011) in similar crosses. However, pod length, number of seeds per pod, 100-seed weight and seed yield per plant recorded high negative heterosis which was in conformity with earlier reports of Subramanian and Muthiah (2001B), Singh et al, (2009). The coefficient of variation $(\mathrm{CV})$ was highest for yield per plant $(85.5 \%)$ followed by pods per plant $(74.7 \%)$, plant height $(50.6 \%)$ and cluster per plant $(50.1 \%)$, indicating there by that maximum variability exists in the segregating populations for these traits (Table-1).

Subsequently the desirable transgressive segregants were observed in $\mathrm{F}_{2}$ progenies for plant height, number of primary branches, cluster per plant and pods per plant. From this study it may be concluded that interspecific hybridization may be used to produce elite population for effective selection for the improvement of these important pulse crops.

\section{References}

Ahandabaskaran, A. and Rangasamy, P (1996). Cytological studies on interspecific hybrids between Vigna radiata and Vigna mungo. Madras Agric.J. 83: 724-726.

Chowdhary, R. K. Chowdhary, J. B. ans Singh V. 
P. (1977). An amphidiploid between Vigna radiata and Vigna mungo.Crop Improv. 4:113-114.

Dana, S. (1967). The cross between Phaseolus xaureux Roxb. And Phaseolus mungo L. Genetica 37: 259-274.

Gosssal, S. S. and Bajaj; Y. P. S. (1983) Interspecific hybridization between Vigna mungo and Vigna radiata through embryo culture.Euphytica 32:129-137.

Gill, R. K., I. Singh, S. Singh and P. Singh (2014). Studies on combining ability for grain yield and component traits in kharif urdbean. Legume Res., 37(6), 575-579.

Jat, S. K., Y. S. Shivay, C. M. Parhar and H. N. Meena (2012). Evaluation of summer legumes for their economic feasibility, nutrient accumulation and soil fertility. J. Food Legumes, 25, 239-242.

Kumar, Anil, Ravi Kant, Singh, S. K. and Singh, Chandra Mohan (2016). Exploitation of hybrid vigour for identification of superior crosses in greengram [Vigna radiata (L.) Wilczek]. Green Farming Vol. 7 (4) : 803806.

Kumar, Anil, Ravi Kant, Singh, S. K., Mishra, S. B. and Kumar, Hemant (2017). Line $\times$ Tester Analysis for Yield and Yield Component Traits in Greengram [Vigna radiata (L.) Wilczek]. Int. J. Agricult. Stat. Sci. Vol. 13(1) 259-263, 2017.

Shanmugam, A. S. Rangasamy. S. R. and Tathnasamy, R. (1985). Study of segregating generations of the interspecific hybrids of the genus Vigna GeneticaAgraria 39:387-400.

Singh, M. N. and Singh, R. M. (1991) Observation on the interspecific hybrids between two species of Vigna. In: Abstract: Golden Jubilee Symp; New Delhi, p. 708709.
Singh, M. N., Singh, R. M. and Singh, U. P. (1996) Studies on hybrids and transgressing segregants in wide crosses of mungbean and urdbean. Indian J. Genet. 56 (1) 109113.

Singh, M. N., Kumar, R., Singh, R. M. and Singh, U.P., (1997). Interspecific hybridization between mungbean and urdbean. Indian $J$. Puls. Res. 10(2) 237-239.

Smartt, J. (1970) Interspecific hybridization between cultivated American sp. of genus Phaseolus. Euphytica, 19: 480-489.

Subramanian, D. (1980) Interspecific hybridization in Vigna. Indian J. Gene. 40: 437-438.

Subramanin, A. and Muthiah, A. R. (2001A). Studies on incompatibility barricrs operating in crosses between Vigna mungo (L) Hepper and Vigna radiata (L) Wilczek Legume Res. 24(2): 87-91

Subramanian, A and Muthiah, A. R. (2001B).Interspecific hybrization between Vigna radiata (L) Wilczek and Vigana mungo (L) Hepper. Legume Res. 24(3): 154-158.

Singh, M. N and Singh S. K (2006). Study of induced amphidiploids derivatives of Vigna radiata $x$ Vigna mungo. Indian J. Genet. 66(3): 245-246.

Singh, S. K., Kumar, Anil and Choudhary, V. K. (2009). Heterosis and Transgressive Segregation Studies in Interspecific crosses Involving Greengram [Vigna radiata (L.) Wilczek] and Blackgram [Vigna mungo (L.) Hepper]. RAU J. of Res. 19 (1\&2) 913.

Singh, S. K., Kumar, Anil and Choudhary, V. K. (2011). Studies on Heterosis and Inbreeding Depression in Mungbean \{Vigna radiata (L.) Wilczek\}. RAU J. of Res. 21 (1\&2), 88-90.

\section{How to cite this article:}

Satish Kumar Singh, M. N. Singh, V. K. Choudhary, M. K. Singh and Aman Tigga. 2020. Studies on the Interspecific Hybrids between Mungbean and Urdbean. Int.J.Curr.Microbiol.App.Sci. 9(05): 364-369. doi: https://doi.org/10.20546/ijcmas.2020.905.041 